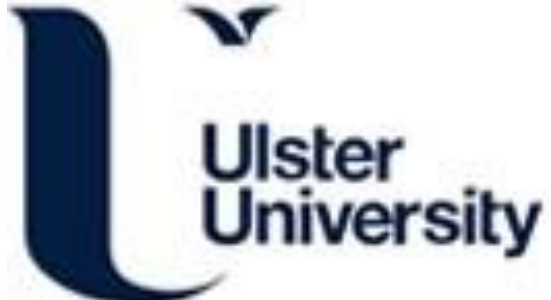

\section{The Latin American network for congenital malformation surveillance: ReLAMC}

Orioli, I., Dolk, H., Lopez-Camelo, J., Groisman, B., Benavides-Lara, A., Gabriel Gimenez, L., Mattos Correa, D., Ascurra, M., de Aquino Bonilha, E., Aurora Canessa-Tapia, M., Vinícius Araújo de França, G., Hurtado-Villa, P., Ibarra-Ramírez, M., Pardo, R., Maria Pastora, D., Zarante, I., Schneider Soares, F., Martinez de Carvalho, F., \& Piola, M. (2020). The Latin American network for congenital malformation surveillance: ReLAMC. American Journal of Medical Genetics, 184(4), 1078-1091. [184C]. https://doi.org/10.1002/ajmg.c.31872

Link to publication record in Ulster University Research Portal

\section{Published in:}

American Journal of Medical Genetics

Publication Status:

Published (in print/issue): 30/12/2020

DOI:

10.1002/ajmg.c.31872

\section{Document Version}

Author Accepted version

\section{General rights}

Copyright for the publications made accessible via Ulster University's Research Portal is retained by the author(s) and / or other copyright owners and it is a condition of accessing these publications that users recognise and abide by the legal requirements associated with these rights.

\section{Take down policy}

The Research Portal is Ulster University's institutional repository that provides access to Ulster's research outputs. Every effort has been made to ensure that content in the Research Portal does not infringe any person's rights, or applicable UK laws. If you discover content in the Research Portal that you believe breaches copyright or violates any law, please contact pure-support@ulster.ac.uk. 
RESEARCH ARTICLE

3 The Latin American Network for Congenital Malformation Surveillance: ReLAMC

5 lêda Maria Orioli ${ }^{1,2}$ Helen Dolk ${ }^{3}$ Jorge Lopez Camelo ${ }^{4}$ Boris Groisman ${ }^{5}$ Adriana Benavides-Lara ${ }^{6}$

6 Lucas Gabriel Gimenez ${ }^{4}$ Daniel Mattos Correa ${ }^{1}$ Marta Ascurra ${ }^{7}$ Eliana de Aquino Bonilha ${ }^{8}$

7 Maria Aurora Canessa-Tapia ${ }^{9}$ Giovanny Vinícius Araújo de França ${ }^{10}$ Paula Hurtado-Villa ${ }^{11}$

8 Marisol Ibarra-Ramírez ${ }^{12}$ Rosa Pardo $^{13}$ Dania Maria Pastora ${ }^{14}$ Ignacio Zarante ${ }^{15}$ Flávia

9 Mahatma Schneider ${ }^{1}$ Flávia Martinez de Carvalho ${ }^{16}$ Mariana Piola ${ }^{4}$ ReLAMC Group ${ }^{17}$

1. ReLAMC (Latin American Network of Congenital Malformation Surveillance) at Department of Genetics, Institute of Biology, Federal University of Rio de Janeiro, Rio de Janeiro, Brazil. 21944-001.

2. Instituto Nacional de Genética Médica Populacional INAGEMP, Porto Alegre, Brazil.

3. Maternal Fetal and Infant Research Centre, Institute of Nursing and Health Research, Ulster University, Shore Rd, Newtownabbey BT370QB.

4. Latin American Collaborative Study of Congenital Malformations (ECLAMC) at Center for Medical Education and Clinical Research (CEMIC-CONICET), Buenos Aires, Argentina.

5. National Network of Congenital Anomalies of Argentina (RENAC), National Center of Medical Genetics (CNGM), National Administration of Laboratories and Health Institutes (ANLIS), National Ministry of Health, Buenos Aires, Argentina. 6. Centro de Registro de Enfermedades Congénitas (CREC), Unidad de Enfermedades Congénitas, Instituto Costarricense de Investigación y Enseñanza en Nutrición y Salud- INCIENSA, Costa Rica

7. Registro Nacional de Defectos Congénitos Paraguay, Programa Nacional de Prevención de Defectos Congénitos (RENADECOPY-PNPDC), Ministerio de Salud Pública y Bienestar Social, Assuncion, Paraguay 
8. Secretaria Municipal da Saúde de São Paulo, Coordenação de Epidemiologia e Informação, Gerência do SINASC, São Paulo, Brazil

9. Regional Register of Congenital Anomalies Maule Health Service, Linares, Chile

10. Secretaria de Vigilância em Saúde, Ministério da Saúde, Brasília, DF, Brasil

11. Facultad de Ciencias de la Salud, Pontificia Universidad Javeriana Cali, Cali, Colombia

12. Departamento de Genética, Facultad de Medicina y Hospital Universitario José E. González, Universidad Autónoma de Nuevo León, Monterrey, México

13. Unidad de Neonatologia, Sección de Genética, Hospital Clínico Universidad de Chile; Unidad de Genética y Enfermedades Metabólicas, Complejo Asistencial Dr. Sótero del Río: Registro Nacional de Anomalías Congénitas de Chile RENACH, Santiago, Chile

14. Facultad de Ciencias Médicas UNAN-León, MINSA, León, Nicaragua.

15. Instituto de Genética Humana, Pontificia Universidad Javeriana Bogotá, Bogotá, Colombia

16. Laboratory of Congenital Malformations Epidemiology (LEMC), Instituto Oswaldo Cruz (IOC), Fundação Oswaldo Cruz (Fiocruz), Rio de Janeiro, RJ, Brazil.

17. ReLAMC Work Group

\section{ReLAMC Work Group:}

CREC, Costa Rica: María de la Paz Barboza-Arguello; ECLAMC: Monica Ritler, Viviana Cosentino, and Alejandra Mariona; PNMC, Ministerio de Salud, Panamá: Ivan Landires PVSDC Bogotá, Colombia: Gloria Gracia, Ithzayana Madariga, and María Paula Aguilera PVSDC Cali, Colombia: Jorge A. Holguín, Claudia M. Orozco and Angie Carolina Carreño; RECUMAC, Centro Nacional de Genética Médica de Cuba: Yudelkis Benitez and Beatriz Suárez; ReDeCon HU, Nuevo-León, México: Laura Elia Martínez de Villarreal; RENAC, Argentina: Rosa Liascovich, Pablo Barbero, and María Paz Bidondo; RENACH, Chile: Cecilia Mellado; RENADECOPY-PNPDC, Paraguay: Fátima Morelli, Marta Bareiro, and Carolina Britez; RRMC SSM Maule: Rosa Gajardo Abarza, and Pedro Pavez Basualto; SINASC-SIM BRAZIL: Valdelaine Etelvina Miranda de Araújo, Eduardo 
1 Marques Macario, and Augusto Cardoso dos Santos; SINASC-SIM MSP: Eneida Sanches Ramos

2 Vico, Cassia Carlin Malteze, and Célia Maria Castex Aly; SVDC, Nicaragua: Dania Maria Pastora,

3 Andres Herrera, Nubia Berrios, and Juan Ramos.

4

5

6 Correspondence

7 Prof. lêda M. Orioli, MD, PhD

8 Department of Genetics

9 Universidade Federal do Rio de Janeiro

10 Rio de Janeiro, 21944-001

11 Brazil

12 Mobile: + 5521994033477

13 Email: orioli@centroin.com.br

14

15 Keywords: Congenital anomaly; surveillance; Latin America; stillbirths; microcephaly;

16 hydrocephaly; Down syndrome; spina bifida; congenital heart defects; talipes; cleft lip and

17 palate; cleft lip; conjoined twins

18

19 Funding information

20 ZikaPlan project, EUHorizon 2020; \#734584; CNPq, Brasil, Grant/Award Number: 440614/2016-

21 3, 424494/2016-7, and 310772/2017-6; CAPES, Grant/Award Number: 88881.130724/2016-01;

22 FAPERJ, Grant/Award Number: E-26/202.617/2019; INAGEMP - CNPq, 465549/2014-4. 


\section{Abstract}

3 The early detection of congenital anomaly epidemics occurs when comparing current with

4 previous frequencies in the same population. The success of epidemiologic surveillance depends

5 on numerous factors, including the accuracy of the rates available in the base period, wide

6 population coverage, and short periodicity of analysis. This study aims to describe the Latin

7 American Network of Congenital Malformation Surveillance: ReLAMC, created to increase

8 epidemiologic surveillance in Latin America. We describe the main steps, tasks, strategies used,

9 and preliminary results. From 2017 to 2019, five national registries (Argentina (RENAC), Brazil

10 (SINASC/SIM-BRS), Chile (RENACH), Costa Rica (CREC), Paraguay (RENADECOPY-PNPDC)), six

11 regional registries (Bogotá (PVSDC-Bogota), Cali (PVSDC-Cali), Maule (RRMC SSM), Nicaragua

12 (SVDC), Nuevo-León (ReDeCon HU), São Paulo (SINASC/SIM-MSP)) and the ECLAMC hospital

13 network sent data to ReLAMC on a total population of 9,152,674 births, with a total of 101,749

14 malformed newborns (1.1\%; $95 \% \mathrm{Cl} 1.10-1.12)$. Of the $9,000,651$ births in countries covering both

15 live and stillbirths, 88,881 were stillborn (0.99\%; 95\% Cl 0.98-0.99), and among stillborns, 6,755

16 were malformed (7.61\%; 95\% Cl 7.44-7.79). The microcephaly rate was 2.45 per 10,000 births

17 (95\% Cl 2.35-2.55), hydrocephaly 3.03 (2.92-3.14), spina bifida 2.89 (2.78-3.00), congenital heart

18 defects 15.53 (15.27-15.79), cleft lip 2.02 (1.93-2.11), cleft palate and lip 2.77 (2.66-2.88), talipes

192.56 (2.46-2.67), conjoined twins 0.16 (0.14-0.19), and Down syndrome 5.33 (5.18-5.48). Each

20 congenital anomaly showed heterogeneity in prevalence rates among registries. The

21 harmonization of data in relation to operational differences between registries is the next step

22 in developing the common ReLAMC database. 


\section{INTRODUCTION}

The last century saw an increased understanding of the causes of congenital anomalies. The genetic origin of several congenital malformation syndromes was described since 1900, but only between 1940 to 1960 did identification of the chromosomal and environmental causes occur (Lancaster, 2011). As opposed to congenital anomalies with genetic causes, the environmental causes appeared in endemic or epidemic status as observed by Gregg (1991) in the rubella embryopathy and by Lenz (1961), Lenz \& Knapp (1962), and McBride (1961) in the thalidomide embryopathy. These two are paradigmatic preventable environmental syndromes. After the thalidomide embryopathy epidemic, several surveillance systems were created

10 (Holtzman \& Khoury, 1986), aiming at the early detection of congenital anomaly epidemics and 11 at identifying and modifying the causal agent.

Nowadays, congenital anomalies are still a leading cause of infant deaths in the world.

13 The well-known morbidity and mortality burden associated with congenital anomalies led to the

14 Resolution 63.17 of the 63rd Assembly of the World Health Organization (WHO) in 2010. This

15 Resolution recommended the development and strengthening of registry and surveillance 16 systems to prevent congenital defects. Since its creation in 1967, ECLAMC (Latin American 17 Collaborative Study of Congenital Malformations) made many efforts to meet these goals in Latin 18 American and Caribbean countries (Poletta et al., 2014). The Pan American Health Organization 19 and the World Bank (2019) have provided an updated description of the more recent efforts in 20 the Region, including the Training Programs initiative to create new surveillance systems.

WHO declared the Zika virus (ZIKV) epidemic a public health emergency in 2016

22 (https://www.who.int/news/item/01-02-2016-who-statement-on-the-first-meeting-of-the-

23 international-health-regulations-(2005)-(ihr-2005)-emergency-committee-on-zika-virus-and-

24 observed-increase-in-neurological-disorders-and-neonatal-malformations), after increased rates 25 of a newly described congenital ZIKV syndrome (Oliveira Melo et al., 2016; Schuler-Faccini et al., 26 2016). Brazilian information available at DATASUS (Marinho et al., 2016) and at ECLAMC 27 databases (Orioli et al., 2017) provided insights into the microcephaly crisis by providing baseline 28 prevalence for the Brazilian Northeast region before the virus entered the continent. Limitations 29 included underreporting of microcephaly cases in DATASUS and the corrections that were 
1 required to the hospital-based prevalence estimates of ECLAMC as well as the small coverage of

2 ECLAMC in epidemic areas. By 2015, Latin America had also established many registries of

3 congenital anomalies and information systems working at regional or national levels. However,

4 those data systems were not networked, preventing further, standardized, and more accurate

5 analyses of the microcephaly rates. In 2016, answering calls from the Brazilian National Council

6 for Scientific and Technological Development (CNPq) and European Union Zika-PLAN project

7 (Wilder-Smith et al., 2019), we proposed creating a Latin American network of congenital

8 malformation registries. We describe here the strategy and methods used and the first results 9 obtained.

\section{METHODS}

\subsection{Latin American Network for Congenital Malformation Surveillance} (ReLAMC): creation

ReLAMC's primary goal is strengthening congenital anomaly surveillance to provide

15 public, online, updated, and reliable reference frequencies for congenital anomalies in Latin America. A new program on congenital anomaly surveillance with a common protocol and

17 mechanisms for information sharing was agreed on for periodic assessment of frequencies of congenital anomalies to detect increases at an earlier stage and confirm rumors coming from any

19 region. ReLAMC also aims to contribute to establishing new registries in the Region and 20 promoting collaborative research on the causes of congenital anomalies.

One strategy used in the construction of ReLAMC was to profit from 50 years of ECLAMC

22 experience in networking. We chose the ECLAMC annual meetings as a host from 2016 to 2019

23 to discuss with the invited Surveillance Program directors the proposed ReLAMC creation project

24 and its further development. When defining the ReLAMC database, another strategy used was 25 following as closely as possible the ICBDSR (International Clearinghouse for Birth Defects 26 Surveillance and Research) since several Latin American programs already send data to the 27 ICBDSR network (Table 1). We also followed the EUROCAT (European Surveillance of Congenital 28 Anomalies) model for the initial design of the Terms of Agreement, data sharing options, the use 
1 of data quality and public health indicators, and web page contents, particularly prevalence tables. The Skeleton Plan with the main steps, definition, and strategies for ReLAMC creation, as well as the initial history, are in Table S1 (Supplementary Material). cover these variables plus a further ten: birth date, place or code of the hospital, mother's place

16 of residence, maternal number of pregnancies, gestational age at birth, birth weight, birth length,

17 cephalic circumference, death date, and prenatal detection of a congenital anomaly. The

18 individual database is automatically converted to the public dataset (aggregate numbers), and the required denominators are similar in the two operational modes. Data not publicly published

\subsection{ReLAMC procedures and databases content}

ReLAMC members send individual or aggregate data every six months to the shared network database via a secure server. The common public dataset contains:

1. The number of defects registered for 97 selected types of congenital anomalies, ICD-10 coded, stratified by sex in each group of live birth or stillbirth, isolated or associated with other defects, and three maternal age categories

2. The number of newborns classified in twenty broad groups of congenital anomalies stratified by sex for each group of live births and stillbirths

3. The number of all live births and stillbirths stratified by sex and by six maternal age quinquennium categories during the six months (denominators) on the website will remain protected for the exclusive use of ReLAMC and the registry that produced them.

Among the 97 selected types of congenital anomalies transmitted to ReLAMC as aggregate data, 21 conditions are listed outside ICD-10 chapter XVII (Congenital malformations, deformations, and chromosomal abnormalities). Seven are embryopathies with or without neonatal infection caused by maternal infection by syphilis (A50), human immunodeficiency virus (HIV) (B24), rubella (P35.0), cytomegalovirus (P35.1), herpes simplex (P35.2), chickenpox virus (P35.8), and Toxoplasma gondii (P37.1), known collectively as STORCH infections which are in 
$1 \quad I C D-10$ chapter I (Certain infectious and parasitic diseases) and XVI (Certain conditions originating

2 in the perinatal period). Also, the newly created code for Zika virus syndrome (P35.4) is in chapter

3 XVI, even if in ReLAMC until 2019, it was P35.8 (Other congenital viral diseases). Table S2

4 (Supplementary Material) shows the ReLAMC list of the 76 congenital anomalies with their ICD-

510 chapter XVII codes and observations and the 21 coded outside ICD-10 chapter XVII.

Mexico City, along with Cuba and Uruguay, are the only places in Latin America where 7 women can undergo abortions during the first 12 weeks of pregnancy regardless of the 8 circumstances (https://www.bbc.com/mundo/noticias-america-latina-45132307). Voluntary 9 termination of pregnancy for fetal anomalies (TOPFA) or other causes occurs in some Latin 10 American countries, although there is a vast difference in accepted legal reasons. This 11 heterogeneity concerning TOPFA and the few cases registered during 2017 and 2018 led us to 12 decide to drop this variable from the data form, but it can be reinstated when appropriate.

13 ReLAMC data quality control calculates the proportion of missing data on obligatory fields 14 and checks that totals are compatible among related fields. Further data quality control is 15 currently done at registry level. More detailed information on ReLAMC structure, governance, 16 operations, data security, and ethics can be found in the ReLAMC Terms of Agreement and 17 Commitments upon request.

\subsection{Data analysis}

The twelve registries described in this work joined ReLAMC at different times, which extended the pilot data sharing from 2017 to 2018. The pilot study tested the data collection forms, last revised in 2019. With the material sent during the pilot study and subsequently, we analyzed the prevalence rates of stillbirths, congenital anomalies, congenital anomalies in stillbirths, and nine selected congenital anomalies for each registry and the combined total. The definition of stillbirth is not uniform among registries, including the delivery of the dead fetus at or after 20 weeks gestation or weighing 350 grams or more when gestation time is unknown. The prevalence rate of stillbirths was calculated per 1,000 births (live births and stillbirths). The

27 prevalence rate of congenital anomalies was calculated per 100 births, and selected congenital anomalies per 10,000 births. The prevalence rate of congenital anomalies in stillbirths was 
1 calculated per 100 stillbirths. The nine selected anomalies were those with the following

2 International Classification of Diseases 10 (ICD-10) codes:

3 - Microcephaly (Q02)

4 - Hydrocephaly (Q03)

5 - Spina bifida (Q05)

6 - Congenital heart defects (Q20 to Q26)

$7 \quad$ - Cleft lip (Q36)

$8 \quad-\quad$ Cleft lip and palate (Q37)

9 - Talipes (Q66)

10 - Conjoined twins (Q89.4)

11 - Down syndrome (Q90)

12 Each anomaly was counted regardless of the presence or absence of another type of 13 congenital anomaly in the same newborn.

14 The Poisson or Binomial exact confidence intervals at 95\% level were calculated for each 15 prevalence rate using the Stata 12 software. All prevalence rates and their lower and upper $95 \%$ 16 confidence intervals for stillbirths, congenital anomalies, congenital anomalies in stillbirths, and 17 nine selected anomalies were displayed graphically in forest plots to allow inter-registry 18 comparison.

19 Each registry provided both the total live birth numbers in their region/nation, and the 20 number covered by the registry. The registry's population coverage in 2017 was calculated.

\section{$22 \quad 3$ RESULTS}

\subsection{Creation history}

The ReLAMC initiative of networking registries in Latin America came as a response to the

25 increase of microcephaly rates during the ZIKV pandemic. In 2016 we invited 11 Latin American 
1 congenital anomaly registries to participate in ReLAMC. The meeting was held together with the 48th ECLAMC annual meeting, and the concept was met with enthusiasm. We invited six new registries in the following year totaling 17 registries involved with the ReLAMC creation. Fourteen registries continued to be involved, and 12 could share data from 2017/1 (Table 1, Figure 1). We have summarized the history of ReLAMC creation and development in Table S1 (Supplementary Material). sharing data and each registry's start year. There were overlapping data in Brazil and Chile

10 national and regional registries, corrected in Table 1 for the national plus regional total. The

11 ECLAMC hospital-based registry has overlapping data with registries from Argentina, Chile, 12 Bogotá, and Cali. Only 18,621 from 58,744 ECLAMC live births are non-overlapping data from 13 Argentina, Bolivia, Peru, and Venezuela hospitals.

ReLAMC covered 3,502,706 Latin American live births in 2017, excluding overlapping

15 live births, 3,484,085 live births from national and regional registries, and 18,621 live births 16 from ECLAMC hospitals not covered by those registries. National registries covered $82.2 \%$ of 17 live births in Argentina, Brazil, Chile, Costa Rica, and Paraguay (3,436,478/4,179,773 live births). 18 In comparison, the regional registries covered 59.3\% of live births in Bogotá D.C. (Colombia), 19 Cali city (Colombia), Maule region (Chile), North-Western Nicaragua (Chinandega and León 20 departments), Nuevo-León state (Mexico), and São Paulo municipality (Brazil) $21(256,321 / 432,153)$ (Table 1$)$. The coverage of live births is heterogeneous among national 22 registries varying from 29.7 to $96 \%$, the same occurring among regional registries with a 23 broader range from 12 to $100 \%$ (Table1). The duration of data collection for each registry varies 24 from 53 years for ECLAMC to four years for national registries in Chile and Paraguay (Table 1).

\subsection{Health Indicators}

From 2017 to 2019, ReLAMC received data on 9,152,674 births. Excluding Paraguay,

27 with data only on live births, there were 88,881 stillbirths in 9,000,651 total births, a general 28 stillbirth prevalence of 9.87 per thousand (95\% Cls $9.81-9.94)$. The rates range from 4 to 11 29 stillbirths per thousand births (Figure 2). 
Among the 9,152,674 births, there were 101,749 newborns registered with congenital anomalies, a rate of $1.11 \%$ (95\% Cls 1.10 - 1.12). These rates range from $1 \%$ to $4 \%$ (Figure 3).

There were 6,755 stillbirths with congenital anomaly among the 88,723 stillbirths, excluding $\mathrm{N}$. León stillbirth data, indicating that $7.61 \%(95 \% \mathrm{Cl} 7.44-7.80)$ of the mortality is associated with congenital anomalies in the ReLAMC data for this period. The proportion of congenital anomalies in stillbirths ranges from $3 \%$ in Costa Rica to $19 \%$ in Chile and $23 \%$ in the ECLAMC hospital network (Figure 4).

\subsection{Congenital anomaly prevalence}

National registries in Argentina, Brazil, Chile, and Costa Rica, and the regional registry

10 of Nuevo-León (8,336,969 births) registered cases for syphilis, cytomegalovirus, and

11 toxoplasmosis, summing up 19 syphilis, five cytomegalovirus, and nine toxoplasmosis cases for

12 2017, a rate of 3.96 per 10,000 births (95\% Cl $2.72-5.56)$. ReLAMC did not receive data from

13 all registries for the selected congenital anomalies coded outside the ICD-10 chapter XVII, 14 including the embryopathies caused by maternal infections during pregnancy.

Table 2 shows each registry's prevalence rate per 10,000 for microcephaly (Figure 5), hydrocephaly, spina bifida, congenital heart defects, cleft lip, cleft lip and palate, talipes,

17 conjoined twins, and Down syndrome (Figure 6). The total number of births used for prevalence 18 rate calculations was 9,133,299 due to missing congenital anomaly information on 19,374

19 births. The data covers $83 \%$ of the expected semesters in the period. All the selected anomalies

20 show heterogeneity in prevalence rate between registries.

\section{DISCUSSION}

Two transnational networks provide a forum for congenital anomaly registries to share

24 data in surveillance and research. The ICBDSR congregate registries from across the world since 251974 (Bermejo-Sanchez et al., 2018), and EUROCAT is a network of population-based registries 26 in the European Union created in 1979 (Boyd et al., 2011). Latin America has a hospital-based 27 network, ECLAMC, with a central database, created in 1967 by Eduardo Castilla (Castilla and 28 Orioli, 2004), that has conducted congenital anomaly surveillance to detect and investigate 29 unusual occurrences in time or space. For time clusters, or epidemics, routine monitoring is 
1 performed, and quarterly data are compared against other equivalent surveillance systems 2 through the ICBDSR, of which ECLAMC was one of the founders. From 1985 with the Registro 3 Cubano de Malformaciones Congénitas (RECUMAC), and 1987, with the Centro de Registro de 4 Enfermedades Congénitas en Costa Rica (CREC), until recent years, population-based national or 5 regional congenital anomaly registries have been set up in many countries in Latin America. Although many are members of ICBDSR, these systems are not networked on a Latin American basis. ReLAMC was created to fill this gap as a transnational network of the Latin American national or regional registries, also integrated with ECLAMC.

National registries cover $82 \%$ of births in the five countries where they operate, with coverage almost complete in Brazil and Costa Rica and lower in Argentina, Chile, and Paraguay.

11 Births not covered are mainly from private hospitals or hospitals not yet participating in the 12 recently created registries as in Chile and Paraguay. Regional registries in three countries that do 13 not have national registries sending data to ReLAMC cover $7.9 \%$ in Nicaragua, $3.7 \%$ in Colombia, 14 and $0.4 \%$ in Mexico. All seven regional registries cover $59.3 \%$ of the cities, municipalities, or states 15 they aim to cover. The higher national than regional registry coverage is expected because most 16 national registries have a mandatory reporting requirement in their country. The initial ReLAMC 17 decision to collect data on overlapping registries, correcting when necessary, was useful to 18 identify differences between national or regional registries in the same country. Also, ReLAMC 19 aims to promote new Latin American registries, and collaborative research on congenital 20 anomalies will be better fulfilled working together with all interested people.

To estimate some public health indicators, we analyzed all data sent to ReLAMC from 222017 to 2019 , a total of 9,152,674 births. Stillbirth rates ranged from 4 to 11 per 1,000 births. 23 They were above 8 per 1,000 in the national registries of Argentina, Brazil, and in ECLAMC. The 24 ECLAMC hospital-based population suffers from the hospital referral effect (Orioli et al., 2017), 25 where prenatally diagnosed fetuses cause referral of delivery to high complexity hospitals, 26 probably explaining the higher ECLAMC mortality rate. The regional stillbirth rate of 7.84 in São

27 Paulo municipality is lower than the national rate of 10.26 per 1.000 births. It is at the upper end 28 of the confidence limits for the aggregate mean rate from 2010 to $2014(7.65,95 \% \mathrm{Cl} 7.47-7.84)$ 29 in São Paulo municipality (Andrews et al., 2017). These authors found high heterogeneity among 
1 municipalities of the São Paulo state in this period (0 to 29.7 per 1.000 births), mirroring what happens throughout Brazil (Andrews et al., 2017). Also, they observed that the stillbirth rate

3 exceeded the neonatal mortality rate (newborn death until 27 completed days) in the perinatal mortality rate (Lawn et al., 2016), increasing the importance of the stillbirth rate as a health 5 indicator.

In 2013, the fetal death rate of 5.96 per 1,000 live births and fetal deaths, described in the USA (McDorman and Gregory, 2015), was lower than the Latin American stillbirth rate (9.6 per 1,000$)$. Also lower than ReLAMC, the rate of fetal deaths at $\geq 23$ weeks was 2.8 per 1,000 live

9 births, in Friuli Venezia Giulia, 2005 to 2013, excluding termination of pregnancy for fetal anomaly 10 (TOPFA) (Monasta el al., 2020). Lower stillbirth rates were also published for Australia, 7.1 per 11 1,000, from 2013 to 2014 (Australian Institute of Health and Welfare, 2018), and the U.K. stillbirth 12 rate is 3.74 per 1,000 (Draper et al., 2019).

There were $7.6 \%$ of stillbirths with registered congenital anomalies. ECLAMC had higher

14 rates of stillbirth, congenital anomaly, and congenital anomaly in stillbirth (22.8\%). Costa Rica 15 presented the lowest rate of malformed stillbirths among the registries with $3.2 \%$. EUROCAT 16 Public Health Indicators calculate congenital anomalies in stillbirths as a proportion of total 17 births, with a rate of 0.5 per 1,000 births (Khoshnood et al., 2011) which with an average stillbirth

18 rate below 3 per 1,000 births means that approximately $16 \%(0.5 / 3)$ are associated with a 19 congenital anomaly. The lower proportions in ReLAMC are likely to be associated with the greater 20 importance of other stillbirth causes and the under-reporting of congenital anomalies among 21 stillbirths.

Fetal deaths occurring antepartum are more prevalent and are associated with many 23 maternal and fetal causes in the developed world (Smith, 2010), while intrapartum stillbirths are 24 generally imputed to lack of high-quality delivery care and represent only ten percent of stillbirths 25 (Lawn et al., 2016). The time of fetal death is not available in our data to separate these two 26 groups. However, the socioeconomic differences in the Latin American populations are likely to 27 play a key role in explaining the observed differences in stillbirth rate and congenital anomaly 28 rate in stillbirth among the registries. 
1 The congenital anomaly rate has several components

2 (https://www.who.int/publications/i/item/9789241548724). These prevalence rates among

3 ReLAMC registries ranged from $1 \%$ to $4 \%$. Choosing a cut-off congenital anomaly rate to indicate

4 under registration is not useful due to the different registries' characteristics. EUROCAT had

5 proposed that rates below $2 \%$ suggest under registration in their system (Loane et al., 2011).

6 National registries had a larger number of births, usually under mandatory rules. Their lower

7 congenital anomaly rates than regional registries possibly occurred because their hospitals

8 preferentially register visible and major defects. The Costa Rica register is an exception having a

9 congenital anomaly rate of over $2.5 \%$, like Cali, Bogotá, and ECLAMC. Another factor that may

10 influence these rates is the length of observation. The length of observation in Costa Rica is until

11 one-year-old, and there is an active search of patients with congenital anomalies, differently from

12 other national registries (Benavides-Lara et al., 2011). The ReLAMC congenital anomaly rate was

13 lower compared to Europe (2017 - 2018), (EUROCAT) (2.54\%; 95\% Cl 2.51 - 2.57), the same

14 occurring with the rate of $2.03 \%(95 \% \mathrm{Cl} 1.98$ - 2.09) described for Utah (USA), 2005 - 2009,

15 (Feldkamp et al., 2017). With ReLAMC consolidation and standardized reporting and quality

16 criteria applied, we expect the prevalence of congenital anomaly to be closer to those reported

17 in Europe and the United States.

18 We compared the prevalence of nine congenital anomalies among registries as

19 preliminary examples of ReLAMC data sharing. We chose microcephaly and hydrocephaly

20 because of their link to the ZIKV epidemic, spina bifida to allow the evaluation of folic acid health

21 policies, congenital heart defects, and Down syndrome because of their high frequency,

22 conjoined twins because there was a suspicion this year (September 2020) of an increase in

23 frequency, and cleft lip, cleft lip and palate, and talipes, together with the defects mentioned

24 before, because they need early detection and treatment.

25 Head circumference is a significant factor in the suspicion and diagnosis of microcephaly

26 and hydrocephaly, alongside image studies and clinical neurology evaluation. Several authors

27 have also associated hydrocephaly and other associated brain damage with the Zika congenital

28 syndrome since the earlier complete descriptions (Mlakar et al., 2016; Soares de Oliveira-

29 Szejnfeld et al., 2016; Alvarado \& Schwartz, 2017; Del Campo et al., 2017). The primary focus on 
1 head circumference measures and the different definitions of microcephaly and hydrocephaly among registries could be the main factors in explaining heterogeneity in rates during the ZIKV epidemic and afterward. In ECLAMC, another factor in explaining increased rates of microcephaly and hydrocephaly derived from its participation in ReLAMC data being restricted to the 2017 year. During this year, the ZIKV epidemics were active in several ECLAMC hospital cities. Brazil's microcephaly rate in 2017 - 2019 (1.65 per 10,000) was lower than rates in other registries. Nevertheless, it was almost three times greater than the Brazilian microcephaly prevalence rate in the 2000 - 2014 period $(0.56$ per 10,000) (Marinho et al., 2016). The inclusion

9 of the 2017 epidemic year in the more recent rate must explain part of the increase, but an 10 increase in the completeness of microcephaly reporting due to the ZIKV epidemic may also 11 contribute to this increase. In the case of Costa Rica, where the prevalence was several times

12 higher than most of the registries, the congenital Zika epidemic, whose peak of cases occurred 13 between 2017 and 2018, caused its baseline to increase almost four times

14 (https://www.inciensa.sa.cr/vigilancia epidemiologica/informes vigilancia/2018/Malformacion 15 es\%20Congenitas/Informe\%20epidemiologico\%20anual\%20defectos\%20congenitos.\%20Costa 16 \%20Rica\%202018.pdf).

The prevalence rates of spina bifida were heterogeneous among ReLAMC registries. Since

18 they are a useful measure of the folic acid fortification health policy (Crider et al., 2018), the 19 registries initiated a spina bifida epidemiological research study to better explain this 20 heterogeneity. The same occurred for congenital heart defects, where the collaborative 21 epidemiological study that has been initiatied is to clarify which differences resulted from coding 22 or resulted from differences in perinatal care resources. Operational changes in 2018 occurred 23 in the forms to send aggregate data to ReLAMC. We added ten new congenital heart defect ICD2410 codes to the earlier seven and eliminated the "other cardiopathies" code. The contribution of 25 these changes to the heterogeneity of congenital heart defect rates must be small since the 26 registries had sent a higher volume of data with the new forms.

27 Several ReLAMC registries presented prevalence rates for cleft lip (Q36) and cleft lip and 28 palate (Q37) that suggested under registration or coding problems. Oral cleft information such 29 as the proportion of each type of cleft could be used when establishing data quality indicators 
1 for congenital anomaly registries (Groisman et al., 2019), and indicated several coding problems

2 in the live birth part of the Brazilian registry (Nascimento et al., 2017). The ICD-10 classification

3 of oral clefts could induce oral cleft coding errors in those registries that use the ICD-10

4 classification without any extension such as the BPA (Nascimento et al., 2017). The ICD-10 BPA

5 codes Q36.90 and Q36.99 allow the separation of unilateral cleft lip from a unspecified cleft lip,

6 and the Q37.99 code allows the registration of an unspecified cleft lip with cleft palate case. The

7 cleft lip prevalence rate is not expected to be close to or greater than the cleft lip and palate rate,

8 and this error can also result when registries primarily register cases with cleft lip with and

9 without cleft palate (Q36 plus Q37) combined. For a long time, this entity has been considered

10 the same anomaly based on the usual occurrence of cleft lip only and cleft lip and palate in the

11 same families (Fogh-Andersen, 1942).

12 The heterogeneity of talipes prevalence rates could be explained by different

13 interpretation of registries sending aggregate as to what must be counted under talipes (Q66).

14 Some registries recorded only equinovarus feet (Q66.0) even if the code Q66 has nine subgroups

15 of feet deformities. Also, there were differences among the registries about the registration of

16 defects according to severity.

17 The Down syndrome prevalence rate is also a useful data quality indicator when shown

18 by maternal age category. We did not analyze the prevalence rates for Down syndrome by

19 maternal age because this stratification of the entire population is not always available. However,

20 all registries except for Brazil have prevalence above 1 per thousand births, as described in the

21 USA and other parts of the world (reviewed by Antonarakis et al., 2020).

22 There was a recent inquiry in ReLAMC about the current conjoined twins' prevalence 23 rates. The ReLAMC registries did not register conjoined twins in the same way. Some registries

24 consider the twins only one case, and others follow other rules considering two cases when there

25 is a theoretical possibility of separation by surgery. Even with this difference in registration, there

26 is no sign of conjoined-twin increased frequency in ReLAMC data.

27 This study presented what we believe should be practical steps, tasks, and processes to

28 help others set up a collaborative network to diminish the burden of congenital anomalies. There

29 were at least two planning weaknesses to mention. First, we did not achieve a more direct 
1 approach of WHO and PAHO to the country health authorities supporting collaboration with

2 ReLAMC, for all Latin American registries that depend on this. PAHO and the WHO sent 3 representatives to the annual meetings. Their support is essential since ReLAMC is not an 4 initiative of a single country, but an agreement between registries with the periodically elected 5 steering committee and director, according to the Terms of Agreement.

The second planning weakness was constructing the ReLAMC database too closely like 7 the ICBDSR to spare duplicate work since several registries already take part in that network. 8 These differences include periodicity of data sending and using coding outside the ICD-10 Chapter 9 XVII when registering the avoidable embryopathies due to maternal infections. We conclude that 10 the few differences with ICBDSR forms are enough that sending data to ReLAMC is a full job, with 11 no saving in time. ReLAMC could not eliminate those differences to carry out its objectives. A successful strategy used in the ReLAMC creation was to profit from 50 years of ECLAMC 13 experience networking. Since 2016, four ReLAMC meetings were held accompanying the ECLAMC 14 Annual Meeting, sharing financial resources and building critical mass for analytical and decision15 making discussions. The collaborative spirit of ECLAMC putting together many researchers, 16 pediatricians, and students over the past 52 years plays a key role in ReLAMC development.

The construction of networks of institutions for the study of causes, epidemiological 18 surveillance, and proposals for preventive measures for congenital anomalies has been taking 19 place in Latin America and the rest of the world for a long time (Bermejo-Sánchez et al., 2018; 20 Cardoso-dos-Santos et al., 2020). In low- and middle-income countries, these constructions are 21 hampered by the lack of continuity of technical staff in charge of implementing public policies, 22 as ReLAMC experienced through its relationship with the registries. In this unfavorable context, 23 the voluntary network of individuals, such as ECLAMC, has preserved institutional collaboration 24 long enough to return technical teams capable of carrying out the institutional execution of 25 health policies. The supranational health agencies, like WHO and regional agencies like PAHO, 26 must recognize and continue supporting these volunteer networks in the under-developed 27 world. It is essential to acknowledge the March of Dimes and CDC roles, which have long been 28 collaborating for international epidemiological surveillance (Mumpe-Mwanja et al., 2019), 
1 including voluntary networks as the ICBDSR (Bermejo-Sanchez et al., 2018), with positive

2 repercussions for Latin America and other parts of the world.

3 The creation of ReLAMC required and still requires an intense effort to gather people

4 around a common interest. It is an ongoing project with as yet uncompleted tasks such as the

5 complete online platform. Since ReLAMC plans to incorporate new registries and help them check

6 their data quality, it will include in its automatic routine the 40 data quality indicators (DQI)

7 developed by Groissman et al. (2019) as Excel DQls tool, freely available in

8 http://www.icbdsr.org/data-quality-indicators-tool/. The next steps also include making the

9 information on birth prevalence rates of select congenital anomalies publicly available on the

10 website portal relamc.org, including charts and tables for the place, birth condition, and time.

11 Consultants will be able to select data for total defects or selected anomalies, for total ReLAMC

12 or any country or register, for live or stillbirths or total, each semester or year. Regarding public

13 health indicators, stillbirth rates by country or registry for the entire population covered and the

14 proportion of stillbirths due to specific or total congenital anomalies will be available.

15 The ReLAMC results of the first three years included data from the pilot study and should

16 be interpreted with caution because they may not represent the reality of the regions analyzed.

17 However, the possibility of comparing data from these twelve Latin American registries allowed

18 a better understanding of operational differences or deficiencies in the registries of congenital

19 anomalies. We expect more rapid progress in improving the epidemiological surveillance of

20 congenital anomalies in Latin America. 


\section{ACKNOWLEDGMENTS}

3 We are indebted to representatives from the OMS (Dr. Thereza Diaz and Dr. Nathalie Roos),

4 PAHO (Dr. Pablo Duran), CDC (Dr. Diana Valencia), and the national registries' representatives

5 from SIVIGILA, Colombia (Dr. Franklyn Prieto), SINASC/SIM, Brazil (Dr. Dacio Rabello Lyra Neto,

6 Dr. Aglaêr Alves da Nóbrega), and RNDCER, Uruguay (Dra. Mariela Larrandaburo), and from

7 RYVEMCE, México (Dr. Osvaldo Mutchnick), which took part in developmental workshops

8 helping the ReLAMC setup. We thank the ECLAMC hospital representatives for hosting the

9 ReLAMC meetings and actively taking part in the discussions.

\section{CONFLICT OF INTEREST}

13 The authors have no conflict of interest to declare.

\section{AUTHOR CONTRIBUTIONS}

Study conception and design: lêda Maria Orioli, Helen Dolk. Acquisition of data: Marta Ascurra,

18 Adriana Benavides, Jorge Lopez Camelo, Aurora Canessa, Giovanny França, Boris Groisman, Paula

19 Hurtado-Villa, Marisol Ibarra-Ramírez, Rosa Pardo, Dania Maria Pastora, Eliana de Aquino

20 Bonilha, Ignacio Zarante. Data organization, and analyses: Lucas Gabriel Gimenez, Mariana Piola,

21 lêda Maria Orioli. Manuscript first draft, preparation, and revisions: Daniel Correa Mattos, Flávia

22 Mahatma Schneider, Flávia Martinez de Carvalho, Helen Dolk, Jorge Lopez Camelo, Boris

23 Groisman Adriana Benavides, Iêda Maria Orioli.

\section{DATA AVAILABILITY STATEMENT}

26 The data that support the findings of this study are available from the corresponding author on

27 reasonable request and after permission of the involved congenital anomaly registries.

29 ORCID

30 Adriana Benavides-Lara https://orcid.org/0000-0002-7121-1388

31 Boris Groisman https://orcid.org/0000-0001-6263-2562 
1 Dania Maria Pastora https://orcid.org/0000-0002-2731-7089

2 Daniel Mattos Correa https://orcid.org/0000-0001-6179-0294

3 Eliana de Aquino Bonilha https://orcid.org/0000-0002-7104-636X

4 Flávia Mahatma Schneider https://orcid.org/0000-0001-5968-1312

5 Flávia Martinez de Carvalho https://orcid.org/0000-0003-2617-9689

6 Giovanny Vinícius Araújo de França https://orcid.org/0000-0002-7530-2017

7 Helen Dolk https://orcid.org/0000-0001-6639-5904

8 leda Maria Orioli https://orcid.org/0000-0003-1863-6229

9 Ignacio Zarante https://orcid.org/0000-0002-0729-6866

10 Jorge Lopez Camelo 0000-0002-3146-5447

11 Lucas Gabriel Gimenez https://orcid.org/0000-0001-9991-3843

12 Mariana Piola https://orcid.org/0000-0002-8472-297X

13 Marisol Ibarra-Ramírez https://orcid.org/0000-0002-3875-4532

14 Marta Ascurra https://orcid.org/0000-0002-3381-3214

15 Paula Hurtado-Villa https://orcid.org/0000-0003-3822-7780

16 Rosa Pardo https://orcid.org/0000-0002-1428-0934

\section{REFERENCES}

Alvarado, M. G., \& Schwartz, D. A. (2017). Zika Virus Infection in Pregnancy, Microcephaly, and Maternal and Fetal Health: What we think, what we know, and what we think we know. Archives of Pathology \& Laboratory Medicine, 141, 26-32.

24 Andrews, K., Bourroul, M. L. M., Fink, G., Grisi, S., Scoleze Ferrer, A. P., Diniz, E. M. de A., \& Brentani, A. (2017). Time to change focus? Transitioning from higher neonatal to higher https://doi.org/10.5858/arpa.2016-0382-RA stillbirth mortality in São Paulo State, Brazil. PLOS ONE, 12, Article e0190060. https://doi.org/10.1371/journal.pone.0190060

Antonarakis, S. E., Skotko, B. G., Rafii, M. S., Strydom, A., Pape, S. E., Bianchi, D. W., Sherman, S. L., \& Reeves, R. H. (2020). Down syndrome. Nature Reviews Disease Primers, 6, 9. 
https://doi.org/10.1038/s41572-019-0143-7

Australian Institute of Health and Welfare. (2018). Perinatal deaths in Australia 2013-2014 Cat. no. PER 94. Canberra: AlHW. https://www.aihw.gov.au/getmedia/78784f2e-2f61-47ea9908-84b34441ae0a/aihw-per-94.pdf.aspx?inline=true

Benavides-Lara, A., Faerron Ángel, J. E., Solís, L. U., José, J., \& Zúñiga, R. (2011). Epidemiología y registro de las cardiopatías congénitas en Costa Rica. Revista Panamericana de Salud Pública, 30, 31-38. https://www.pubmed.ncbi.nlm.nih.gov/22159648

Bermejo-Sánchez, E., Botto, L. D., Feldkamp, M. L., Groisman, B., \& Mastroiacovo, P. (2018). Value of sharing and networking among birth defects surveillance programs: an ICBDSR perspective. Journal of Community Genetics, 9, 411-415. https://doi.org/10.1007/s12687018-0387-z

Boyd, P. A., Haeusler, M., Barisic, I., Loane, M., Garne, E., \& Dolk, H. (2011). Paper 1: The EUROCAT network-organization and processes. Birth Defects Research Part A: Clinical and Molecular Teratology, 91(S1), S2-S15. https://doi.org/10.1002/bdra.20780

Cardoso-dos-Santos, A. C., Magalhães, V. S., Medeiros-de-Souza, A. C., Bremm, J. M., Alves, R. F. S., Araujo, V. E. M. de, Macario, E. M., Oliveira, W. K. de, \& França, G. V. A. de. (2020). Redes internacionais de colaboração para a vigilância das anomalias congênitas: uma revisão narrativa. Epidemiologia e Serviços de Saúde, 29, Article e2020093. https://doi.org/10.5123/S1679-49742020000400003

Castilla, E. E., \& Orioli, I. M. (2004). ECLAMC: The Latin-American Collaborative Study of Congenital Malformations. Community Genetics, 7, 76-94. https://doi.org/10.1159/000080776

Crider, K. S., Qi, Y. P., Devine, O., Tinker, S. C., \& Berry, R. J. (2018). Modeling the impact of folic acid fortification and supplementation on red blood cell folate concentrations and predicted neural tube defect risk in the United States: have we reached optimal prevention? The American Journal of Clinical Nutrition, 107, 1027-1034. https://doi.org/10.1093/ajcn/nqy065

Del Campo, M., Feitosa, I. M., Ribeiro, E. M., Horovitz, D. D., Pessoa, A. L., França, G. V., GarcíaAlix, A., Doriqui, M. J., Wanderley, H. Y., Sanseverino, M.V., Neri, J. I., Pina-Neto, J.M., Santos, 
E.S., Verçosa, I., Cernach, M.C., Medeiros, P.F., Kerbage, S.C., Silva, A.A., van der Linden, V., ... Schuler-Faccini, L. (2017). The phenotypic spectrum of congenital Zika syndrome. American Journal of Medical Genetics Part A, 173, 841-857. https://doi: 10.1002/ajmg.a.38170

Draper ES, Gallimore ID, Smith LK, Kurinczuk JJ, Smith PW, Boby T, Fenton AC, Manktelow BN, on behalf of the MBRRACE-UK Collaboration. (2019). MBRRACE-UK Perinatal Mortality Surveillance Report, UK Perinatal Deaths for Births from January to December 2017. Leicester: The Infant Mortality and Morbidity Studies, Department of Health Sciences, University of Leicester.

Feldkamp, M. L., Carey, J. C., Byrne, J. L. B., Krikov, S., \& Botto, L. D. (2017). Etiology and clinical presentation of birth defects: population based study. British Medical Journal, 357, j2249. https://doi.org/10.1136/bmj.j2249

Fogh- Andersen, P. (1942). Inheritance of harelip and cleft palate. Nyt nordisk Forlag.

Gregg, N. M. (1991). Congenital cataract following German measles in the mother. 1941. Australian and New Zealand Journal of Ophthalmology, 19, 267-276. http://www.ncbi.nlm.nih.gov/pubmed/1789963

Groisman, B., Mastroiacovo, P., Barbero, P., Bidondo, M. P., Liascovich, R., \& Botto, L. D. (2019). A proposal for the systematic assessment of data quality indicators in birth defects surveillance. Birth Defects Research, 111, 324-332. https://doi.org/10.1002/bdr2.1474

Holtzman, N. A., \& Khoury, M. J. (1986). Monitoring for Congenital Malformations. Annual Review of Public Health, 7, 237-266. https://doi.org/10.1146/annurev.pu.07.050186.001321

Khoshnood, B., Greenlees, R., Loane, M., \& Dolk, H. (2011). Paper 2: EUROCAT public health indicators for congenital anomalies in Europe. Birth Defects Research Part A: Clinical and Molecular Teratology, 91, S16-S22. https://doi.org/10.1002/bdra.20776

Lancaster, P. A. L. (2011). Causes of birth defects: Lessons from history. Congenital Anomalies, 51, 2-5. https://doi.org/10.1111/j.1741-4520.2010.00311.x

Lawn, J. E., Blencowe, H., Waiswa, P., Amouzou, A., Mathers, C., Hogan, D., Flenady, V., Frøen, J. F., Qureshi, Z. U., Calderwood, C., Shiekh, S., Jassir, F. B., You, D., McClure, E. M., Mathai, M., Cousens, S., Flenady, V., Frøen, J. F., Kinney, M. V, ... Draper, E. S. (2016). Stillbirths: rates, 
risk factors, and acceleration towards 2030. The Lancet, 387, 587-603. https://doi.org/10.1016/S0140-6736(15)00837-5

Lenz, W. (1961, November 19). On the exogenous origin of malformations of the extremity [Discussion contribution on the lecture by RA Pfeiffer and $\mathrm{K}$ Kosenow]. Meeting of the Association of Paediatricians, Rhineland-Westphalia, Dusseldorf, Germany.

Lenz, W. \& Knapp K. (1962). Thalidomide embryopathy. Archives of Environmental Health, 5, 100105. https://pubmed.ncbi.nlm.nih.gov/14464040/

Loane, M., Dolk, H., Garne, E., \& Greenlees, R. (2011). Paper 3: EUROCAT data quality indicators for population-based registries of congenital anomalies. Birth Defects Research Part A: Clinical and Molecular Teratology, 91, S23-S30.

https://doi.org/10.1002/bdra.20779

McDorman, M. F., \& Gregory, E. C. W. (2015). Fetal and Perinatal Mortality: United States, 2013. National Vital Statistics Reports: From the Centers for Disease Control and Prevention, National Center for Health Statistics, National Vital Statistics System, 64, 1-24. http://www.ncbi.nlm.nih.gov/pubmed/26222771

Marinho, F., Araújo, V. E. M. de, Porto, D. L., Ferreira, H. L., Coelho, M. R. S., Lecca, R. C. R., Oliveira, H. de, Poncioni, I. P. A., Maranhão, M. H. N., Mendes, Y. M. M. B., Fernandes, R. M., Lima, R. B. de, Rabello, D. L. (2016). Microcefalia no Brasil: prevalência e caracterização dos casos a partir do Sistema de Informações sobre Nascidos Vivos (Sinasc), 2000-2015. Epidemiologia e Serviços de Saúde, 25, 701-712. https//doi: 10.5123/S167949742016000400004

McBride, W. G. (1961). Thalidomide and congenital abnormalities. The Lancet, 2, 1358.

Mlakar, J., Korva, M., Tul, N., Popović, M., Poljšak-Prijatelj, M., Mraz, J., Kolenc, M., Resman Rus, K., Vesnaver Vipotnik, T., Fabjan Vodušek, V., Vizjak, A., Pižem, J., Petrovec, M., \& Avšič Županc, T. (2016). Zika Virus Associated with Microcephaly. New England Journal of Medicine, 374, 951-958. https://doi.org/10.1056/NEJMoa1600651

Monasta, L., Giangreco, M., Ancona, E., Barbone, F., Bet, E., Boschian-Bailo, P., Cacciaguerra, G., Cagnacci, A., Canton, M., Casarotto, M., Comar, M., Contardo, S., De Agostini, M., De Seta, F., Del Ben, G., Di Loreto, C., Driul, L., Facchin, S., Giornelli, R., ... Alberico, S. (2020). 
Retrospective study $2005-2015$ of all cases of fetal death occurred at $\geq 23$ gestational weeks, in Friuli Venezia Giulia, Italy. BMC Pregnancy and Childbirth, 20, 384. https://doi.org/10.1186/s12884-020-03074-9

Mumpe-Mwanja, D., Barlow-Mosha, L., Williamson, D., Valencia, D., Serunjogi, R., Kakande, A., Namale-Matovu, J., Nankunda, J., Birabwa-Male, D., Okwero, M. A., Nsungwa-Sabiiti, J., \& Musoke, P. (2019). A hospital-based birth defects surveillance system in Kampala, Uganda. BMC Pregnancy and Childbirth, 19, 372. https:/doi.org/10.1186/s12884-019-2542-x

Nascimento, R. L., Castilla, E. E., Dutra, M. da G., \& Orioli, I. M. (2018). ICD-10 impact on ascertainment and accuracy of oral cleft cases as recorded by the Brazilian national live birth information system. American Journal of Medical Genetics Part A, 176, 907-914. https://doi.org/10.1002/ajmg.a.38634

Oliveira Melo, A. S., Malinger, G., Ximenes, R., Szejnfeld, P.O., Alves Sampaio, S., Bispo de Filippis, A. M. (2016). Zika virus intrauterine infection causes fetal brain abnormality and microcephaly: tip of the iceberg? Ultrasound in Obstetrics \& Gynecology, 47, 6-7. https://doi: 10.1002/uog.15831

Orioli, I. M., Dolk, H., Lopez-Camelo, J. S., Mattos, D., Poletta, F. A., Dutra, M. G., Carvalho, F. M., \& Castilla, E. E. (2017). Prevalence and clinical profile of microcephaly in South America preZika, 2005-14: prevalence and case-control study. British Medical Journal, j5018. https://doi.org/10.1136/bmj.j5018

Pan American Health Organization and the World Bank (2019). Present and Future of Birth Defects Surveillance in the Americas (Vol 3). Washington, D.C.: PAHO, World Bank. https://iris.paho.org/handle/10665.2/51899

Poletta, F. A., Gili, J. A., \& Castilla, E. E. (2014). Latin American Collaborative Study of Congenital Malformations (ECLAMC): A Model for Health Collaborative Studies. Public Health Genomics, 17, 61-67. https://doi.org/10.1159/000356568

Royal College of Obstetricians and Gynaecologists (2016). Each Baby Counts: 2015 Full Report. London, RCOG. https://www.rcog.org.uk/globalassets/documents/guidelines/research-audit/each-baby-counts-2015-full-report.pdf

Schuler-Faccini, L., Ribeiro, E. M., Feitosa, I. M., Horovitz, D. D., Cavalcanti, D. P., Pessoa, A., 
Doriqui, M. J., Neri, J. I., Neto, J. M., Wanderley, H. Y., Cernach, M., El-Husny, A. S., Pone, M. V., Serao, C. L., Sanseverino, M. T.; Brazilian Medical Genetics Society-Zika Embryopathy Task Force. (2016). Possible Association Between Zika Virus Infection and Microcephaly Brazil, 2015. Morbidity and Mortality Weekly Report 65, 59-62. doi: 10.15585/mmwr.mm6503e2

Smith, G. C. S. (2010). Predicting antepartum stillbirth. Clinical Obstetrics and Gynecology, 53, 597-606. https://doi.org/10.1097/GRF.0b013e3181eb64a6

Soares de Oliveira-Szejnfeld, P. S., Levine, D., Melo, A. S. O., Amorim, M. M. R., Batista, A. G. M., Chimelli, L., Tanuri, A., Aguiar, R. S., Malinger, G., Ximenes, R., Robertson, R., Szejnfeld, J., \& Tovar-Moll, F. (2016). Congenital brain abnormalities and Zika virus: What the radiologist can expect to see prenatally and postnatally. Radiology, 281, 203-218. https://doi.org/10.1148/radiol.2016161584

Walani, S. R. \& Biermann, J (2017). March of Dimes Foundation: leading the way to birth defects prevention. Public Health Review, 38, 12. https://doi: 10.1186/s40985-017-0058-3

Wilder-Smith A., Preet R., Brickley E. B., Ximenes R. A. A., Miranda-Filho D. B., Turchi Martelli, C. M., Araújo T. V. B., Montarroyos U. R., Moreira M. E., Turchi M.D., Solomon T., Jacobs B. C., Villamizar C. P., Osorio L., de Filippis, A. M. B., Neyts, J., Kaptein, S., Huits, R., Ariën, ..., Massad, E. (2019). Global Health Action, 12, 1666566. https://doi: 10.1080/16549716.2019.1666566

\section{SUPPORTING INFORMATION}

Additional supporting information may be found online in the Supporting Information section at the end of this article. 
FIGURE LEGENDS

Fig. 1. National and Regional Registries, and ECLAMC hospital network sending data to 6 ReLAMC, 2017 to 2019.

Fig. 2. ReLAMC prevalence of stillbirths per 1,000 births, 2017 to 2019.

Fig. 3. ReLAMC prevalence of congenital anomalies per 100 births, 2017 to 2019.

Fig. 4. ReLAMC prevalence of congenital anomalies in stillbirths per 100 stillbirths, 2017 10 to 2019.

Fig. 5. ReLAMC prevalence of microcephaly per 10,000 births, 2017 to 2019. 
Table 1. Coverage of Latin American live births in 2017 by ReLAMC registries

\begin{tabular}{|c|c|c|c|c|c|c|c|c|c|}
\hline Registry Initials & Start year & Name & Coverage & $\begin{array}{l}\text { Country or } \\
\text { Region }\end{array}$ & $\begin{array}{l}\text { Length of } \\
\text { observation }\end{array}$ & Mandatory & $\begin{array}{c}\text { Registry } \\
\text { Annual live } \\
\text { births } 2017\end{array}$ & $\begin{array}{l}\text { Country/ } \\
\text { Region } \\
\text { Annual live } \\
\text { births } 2017\end{array}$ & $\begin{array}{c}\% \\
\text { Country/R } \\
\text { egion } \\
\text { covered }\end{array}$ \\
\hline SINASC-SIM BRAZIL & $1975-2000$ & $\begin{array}{c}\text { Sistema de Informação sobre } \\
\text { Nascidos Vivos - Sistema de } \\
\text { Informação sobre Mortalidade } \\
\text { do Brasil }\end{array}$ & National & Brasil & $\begin{array}{c}\text { At birth } \\
\text { (SINASC) } \\
1 \text { year (SIM) }\end{array}$ & Yes & $2,923,535$ & $3,045,349$ & 96.0 \\
\hline CREC $\S$ & 1987 & $\begin{array}{l}\text { Centro de Registro de } \\
\text { Enfermedades Congénitas }\end{array}$ & National & Costa Rica & 1 year & Yes & 68,479 & 71,332 & 96.0 \\
\hline RENAC $\S$ & 2009 & $\begin{array}{l}\text { Registro de Anomalías } \\
\text { Congénitas de Argentina }\end{array}$ & National & Argentina & $\begin{array}{l}\text { Maternity } \\
\text { discharge }\end{array}$ & No & 274,079 & 728,011 & 37.7 \\
\hline RENACH & 2016 & $\begin{array}{l}\text { Registro Nacional de Anomalías } \\
\text { Congénitas de Chile }\end{array}$ & National & Chile & $\begin{array}{l}\text { Maternity } \\
\text { discharge }\end{array}$ & Yes & 136,453 & 219,186 & 62.2 \\
\hline RENADECOPY-PNPDC & 2016 & $\begin{array}{l}\text { Programa Nacional de } \\
\text { Prevención de Defectos } \\
\text { Congénitos }\end{array}$ & National & Paraguay & 1 year & No & 33,932 & 115,895 & 29.7 \\
\hline
\end{tabular}




\begin{tabular}{|c|c|c|c|c|c|c|c|c|c|}
\hline SINASC-SIM MSP ${ }^{\dagger}$ & $1975-2000$ & $\begin{array}{l}\text { Sistema de Informação sobre } \\
\text { Nascidos Vivos - Sistema de } \\
\text { Informação sobre Mortalidade } \\
\text { do Município de São Paulo }\end{array}$ & Regional & $\begin{array}{l}\text { São Paulo } \\
\text { Municipality }\end{array}$ & $\begin{array}{c}\text { At birth } \\
\text { (SINASC) } \\
1 \text { year (SIM) }\end{array}$ & Yes & 196,082 & 196082 & 100.0 \\
\hline PVSDC Bogotá § & 2001 & $\begin{array}{l}\text { Programa de Vigilancia y } \\
\text { Seguimiento de Defectos } \\
\text { Congénitos Bogotá }\end{array}$ & Regional & Bogota & $\begin{array}{l}\text { Maternity } \\
\text { discharge }\end{array}$ & No & 15,255 & 94,896 & 16.1 \\
\hline RRMC SSM Maule† § & 2003 & $\begin{array}{c}\text { Registro Regional de } \\
\text { Malformaciones Congénitas del } \\
\text { Maule }\end{array}$ & Regional & Maule & $\begin{array}{l}\text { Maternity } \\
\text { discharge }\end{array}$ & No & 12,632 & 14,114 & 89.5 \\
\hline SVDC & 2006 & $\begin{array}{l}\text { Sistema de Vigilancia de } \\
\text { Defectos Congénitos }\end{array}$ & Regional & Nicaragua & $\begin{array}{l}\text { Maternity } \\
\text { discharge }\end{array}$ & No & 10,684 & 15,263 & 70.0 \\
\hline PVSDC Cali § & 2010 & $\begin{array}{l}\text { Programa de Vigilancia y } \\
\text { Seguimiento de Defectos } \\
\text { Congénitos Cali }\end{array}$ & Regional & Cali & $\begin{array}{l}\text { Maternity } \\
\text { discharge }\end{array}$ & No & 12,399 & 34,556 & 35.9 \\
\hline ReDeCon HU § & 2011 & $\begin{array}{l}\text { Registro de Defectos } \\
\text { Congénitos Hospital } \\
\text { Universitario UANL }\end{array}$ & Regional & Nuevo-León & $\begin{array}{l}\text { Maternity } \\
\text { discharge }\end{array}$ & No & 9,269 & 77,242 & 12.0 \\
\hline
\end{tabular}




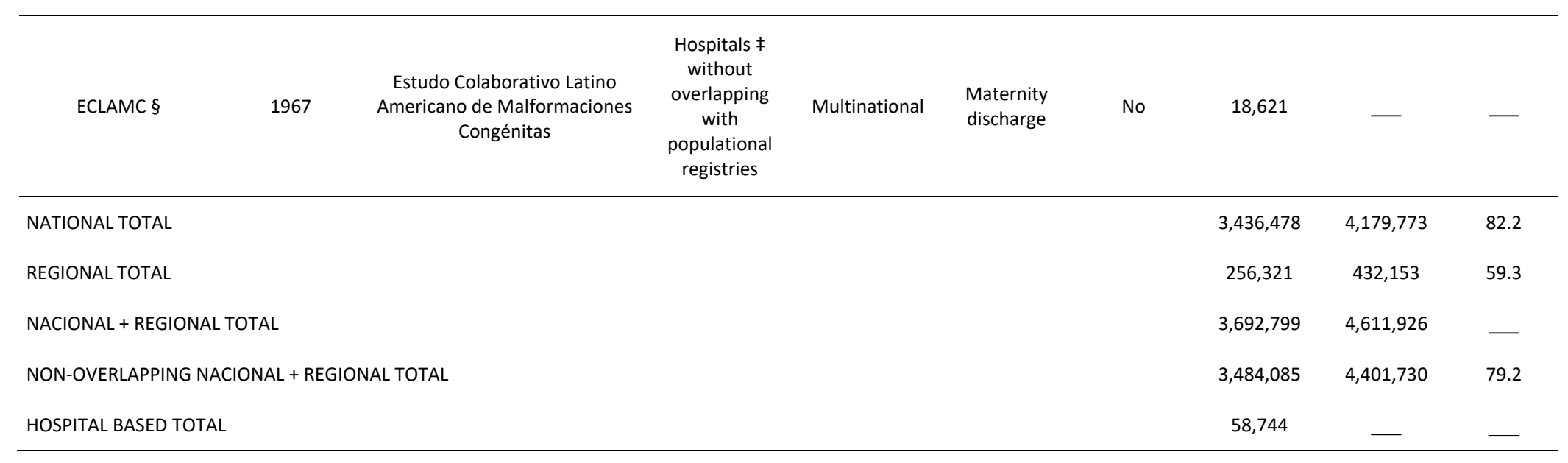

+Regional registries that overlapped with the national registries in ReLAMC data.

¥ Hospitals from La Plata and Lomas de Zamorra (Buenos Aires province, Argentina); La Paz (La Paz province) and Tarija (Tarija province), Bolivia; Lima Autonomous Province (Peru);

Pereira (Risaralda province, Colombia); Coro (Falcon state, Venezuela).

$\S$ Latin American registries also sending data to the ICBDSR. 
Table S1. Skeleton Plan for ReLAMC creation: steps, definition, and history.

\begin{tabular}{|c|c|}
\hline $\begin{array}{l}\text { ReLAMC } \\
\text { SKELETON PLAN }\end{array}$ & DESCRIPTION \\
\hline \multirow[t]{4}{*}{ STEPS } & $\begin{array}{l}\text { 1. To design a complete network project including a Terms of Agreement } \\
\text { and Commitments to be signed by participating Surveillance Programs } \\
\text { and ReLAMC regarding statutory aspects and the basic operational } \\
\text { mode manual. }\end{array}$ \\
\hline & $\begin{array}{l}\text { 2. To define the ReLAMC databases, classifying the variables as obligatory } \\
\text { or optional to allow wider participation of the programs. }\end{array}$ \\
\hline & $\begin{array}{l}\text { 3. To put together the principal actors to discuss the project and to decide } \\
\text { the final operational mode. }\end{array}$ \\
\hline & $\begin{array}{l}\text { 4. To construct a web platform to allow the secure sending and reception } \\
\text { of data, semiannual updating of the ReLAMC databases, and public } \\
\text { consultation on congenital anomalies frequencies. }\end{array}$ \\
\hline STRATEGIES & 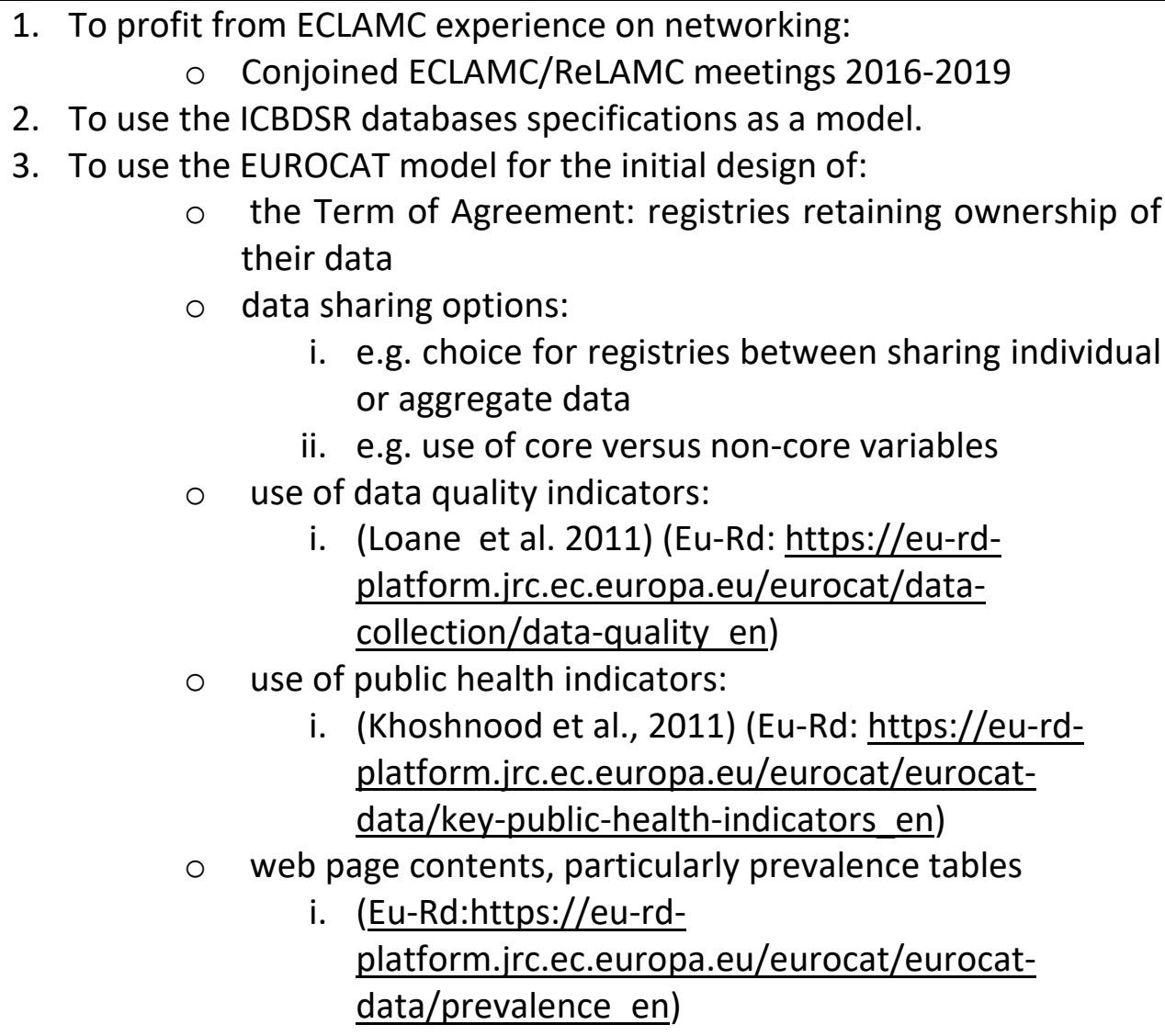 \\
\hline
\end{tabular}




\begin{tabular}{|c|c|}
\hline $\begin{array}{l}\text { ReLAMC } \\
\text { DEFINITION }\end{array}$ & $\begin{array}{l}\text { ReLAMC is formed by the registries that decide to take part, and that can } \\
\text { follow the conditions set out in its Terms of Agreement and } \\
\text { Commitments. Each registry has one vote in the annual general } \\
\text { assembly. The right to vote is independent of the type of population } \\
\text { covered, and whether it is multinational, national, regional, or hospital, } \\
\text { or aggregated or individual data can be provided. }\end{array}$ \\
\hline $\begin{array}{r}\text { PRE-HISTORY } \\
2016\end{array}$ & $\begin{array}{l}\text { ReLAMC project submitted for funding to CNPq - Combate ao Vírus Zika - } \\
\text { Brasil, and CE - Horizon } 2020 \text { - Zika Plan. } \\
\text { Invitation to Latin American congenital anomalies registries we knew for } \\
\text { the First ReLAMC Meeting to be held together with the ECLAMC Annual } \\
\text { Meeting. } \\
\text { Sending previously written material with detailed ReLAMC proposition to } \\
\text { each registry invited to participate in the ReLAMC meeting workshops. }\end{array}$ \\
\hline HISTORY & Annual Meetings \\
\hline $\begin{array}{l}\text { November } 2016 \\
1^{\text {st }} \text { ReLAMC \& } \\
48^{\text {th }} \text { ECLAMC } \\
\text { Annual Meeting, } \\
\text { Buenos Aires, } \\
\text { Argentina. }\end{array}$ & $\begin{array}{l}\text { Participants registries: Argentina (RENAC), Bogotá (PVSDC-Bogota), Brazil } \\
\text { (SINASC/SIM-BRS), Cali (PVSDC-Cali), Chile (RENACH), Cuba } \\
\text { (RECUMAC), Maule (RRMC SSM), and the ECLAMC network currently } \\
\text { with hospitals from Argentina, Bolivia, Brazil, Chile, Colombia, Peru, } \\
\text { and Venezuela. } \\
\text { Dr. Helen Dolk, former EUROCAT director (1999-2014), and Dr. Joan } \\
\text { Morris member of the EUROCAT Steering Committee. } \\
\text { CDC sent representative to help on creating the network.nt representative } \\
\text { to help on creating the network. } \\
\text { The ReLAMC concept was met with enthusiasm, and negotiations around } \\
\text { a common protocol started. }\end{array}$ \\
\hline $\begin{array}{l}\text { November } 2017 \\
2^{\text {st }} \text { ReLAMC \& } \\
49^{\text {th }} \text { ECLAMC } \\
\text { Annual Meeting, } \\
\text { Pilar, Buenos } \\
\text { Aires province, } \\
\text { Argentina. }\end{array}$ & $\begin{array}{l}\text { Participants registries: Argentina (RENAC), Bogotá (PVSDC-Bogota), Brazil } \\
\text { (SINASC/SIM-BRS), Cali (PVSDC-Cali), Chile (RENACH), Cuba } \\
\text { (RECUMAC), Maule (RRMC SSM), ECLAMC network, Colombia } \\
\text { (SIVIGILA), Panamá (PNMC), Paraguay (RENADECOPY-PNPDC), } \\
\text { Nicaragua (SVDC), Nuevo-León (ReDeCon HU), São Paulo (SINASC/SIM- } \\
\text { MSP), Uruguay (RNDCER), and Mexico (RYVENCE). } \\
\text { Dr. Helen Dolk, former EUROCAT director (1999- 2014), and Dr. Joan } \\
\text { Morris member of the EUROCAT Steering Committee. } \\
\text { WHO, PAHO, and CDC sent representatives to share their international } \\
\text { experience and support on creating the network. } \\
\text { A protocol was exhaustively debated to ensure the feasibility of all } \\
\text { members' participation and led to a Terms of Agreement between }\end{array}$ \\
\hline
\end{tabular}




\begin{tabular}{|c|c|}
\hline & $\begin{array}{l}\text { parties. The participants discussed details about the network's } \\
\text { structure and governance and appointed a pro-tempore director and } \\
\text { steering committee. }\end{array}$ \\
\hline $\begin{array}{l}\text { November } 2018 \\
3^{\text {st }} \text { ReLAMC \& } \\
50^{\text {th }} \text { ECLAMC } \\
\text { Annual Meeting } \\
\text { Pilar, PABA, } \\
\text { Argentina. }\end{array}$ & $\begin{array}{l}\text { Participants registries: Argentina (RENAC), Bogotá (PVSDC-Bogota), Brazil } \\
\text { (SINASC/SIM-BRS), Cali (PVSDC-Cali), Chile (RENACH), Costa Rica } \\
\text { (CREC), Cuba (RECUMAC), Maule (RRMC SSM), ECLAMC network, } \\
\text { Panamá (PNMC), Paraguay (RENADECOPY-PNPDC), Nicaragua (SVDC), } \\
\text { Nuevo-León (ReDeCon HU), São Paulo (SINASC/SIM-MSP). } \\
\text { Dr. Helen Dolk, former EUROCAT director (1999 - 2014), and Dr. Joan } \\
\text { Morris member of the EUROCAT Steering Committee. } \\
\text { WHO and the PAHO sent representatives that actively participate in } \\
\text { lectures and workshops. } \\
\text { The data-sharing pilot project results were discussed. the first General } \\
\text { Assembly was realized, and elected the definitive board members. }\end{array}$ \\
\hline $\begin{array}{l}\text { November } 2019 \\
4^{\text {st }} \text { ReLAMC \& } \\
51^{\text {th }} \text { ECLAMC } \\
\text { Annual Meeting } \\
\text { Caxias do Sul, RS, } \\
\text { Brasil }\end{array}$ & $\begin{array}{l}\text { Participants registries: Bogotá (PVSDC-Bogota), Brazil (SINASC/SIM-BRS), } \\
\text { Cali (PVSDC-Cali), Chile (RENACH), Costa Rica (CREC), Cuba (RECUMAC), } \\
\text { Maule (RRMC SSM), ECLAMC network, Panamá (PNMC), Paraguay } \\
\text { (RENADECOPY-PNPDC), Nicaragua (SVDC), São Paulo (SINASC/SIM- } \\
\text { MSP). } \\
\text { Dr. Joan Morris member of the EUROCAT Steering Committee. } \\
\text { The WHO sent representative that actively took part in lectures and } \\
\text { workshops } \\
\text { The results from the first ReLAMC collaborative research project on } \\
\text { microcephaly were presented. } \\
\text { The ReLAMC assembly approved three news collaborative projects, on } \\
\text { spina bifida, on congenital anomalies in adolescent mothers, and on } \\
\text { congenital heart defects proposed respectively by RENACH, RECUMAC, } \\
\text { and CREC. }\end{array}$ \\
\hline $\begin{array}{l}\text { November } 2020 \\
5^{\text {st }} \text { ReLAMC \& } \\
52^{\text {th }} \text { ECLAMC } \\
\text { Annual Meeting }\end{array}$ & $\begin{array}{l}\text { Cancelled the annual meeting programed to August } 30 \text { - September 3rd } \\
\text { New virtual meeting programmed to December } 11-12 \text {. }\end{array}$ \\
\hline $\begin{array}{l}\text { MEMBERSHIP } \\
\text { HISTORY } \\
2017-2020\end{array}$ & $\begin{array}{l}\text { Registries from Argentina (RENAC), Bogotá (PVSDC-Bogota), Cali (PVSDC- } \\
\text { Cali), Costa Rica (CREC), Maule (RRMC SSM), ECLAMC network, } \\
\text { Panamá (PNMC), Paraguay (RENADECOPY-PNPDC), Nicaragua (SVDC), } \\
\text { and Nuevo-León (ReDeCon HU) have signed the Terms of Agreement } \\
\text { with ReLAMC. }\end{array}$ \\
\hline
\end{tabular}


Table 2. Prevalence rates per 10,000 births of nine congenital anomalies, by ReLAMC registries localities, 2017 to 2019

\begin{tabular}{|c|c|c|c|c|c|c|c|c|c|c|c|c|c|}
\hline & BRAZIL & SÃO PAULO & ARGENTINA & CHILE & COSTA RICA & PARAGUAY & ECLAMC & CALI & BOGOTÁ & NUEVO LEÓN & NICARAGUA & MAULE & $\overline{\text { TOTAL }}$ \\
\hline Q002 cases & 1245 & 108 & 89 & 135 & 461 & 84 & 49 & 21 & 19 & 10 & 12 & 1 & 2,234 \\
\hline Microcephaly prev., & 1.65 & 2.17 & 3.25 & 4.98 & 22.77 & 5.53 & 8.25 & 5.91 & 6.01 & 4.44 & 8.42 & 1.56 & 2.45 \\
\hline $95 \% \mathrm{Cl}^{\dagger}$ & $1.55-1.74$ & $1.76-2.58$ & $2.57-3.92$ & $4.14-5.82$ & $20.69-24.85$ & $4.34-6.71$ & $5.94-10.56$ & $3.38-8.44$ & $3.31-8.71$ & $1.69-7.20$ & $3.66-13.19$ & $-1.50-4.62$ & $2.35-2.55$ \\
\hline Q03 cases & 1961 & 207 & 215 & 74 & 78 & 60 & 111 & 10 & 30 & 10 & 10 & 0 & 2,766 \\
\hline Hydrocephaly prev., & 2.59 & 4.16 & 7.84 & 2.73 & 3.85 & 3.95 & 18.68 & 2.82 & 9.48 & 4.44 & 7.02 & 0.00 & 3.03 \\
\hline $95 \% \mathrm{Cl}$ & $2.48-2.71$ & $3.60-4.73$ & $6.80-8.89$ & 2.11-3.35 & $3.00-4.71$ & $2.95-4.95$ & $15.21-22.16$ & $1.07-4.56$ & $6.09-12.88$ & $1.69-7.20$ & $2.67-11.37$ & $0.00-0.00$ & $2.92-3.14$ \\
\hline Q05 cases & 2022 & 167 & 155 & 79 & 57 & 60 & 56 & 4 & 5 & 20 & 12 & 0 & 2,637 \\
\hline Spina bifida prev. & 2.67 & 3.36 & 5.66 & 2.91 & 2.82 & 3.95 & 9.43 & 1.13 & 1.58 & 8.88 & 8.42 & 0.00 & 2.89 \\
\hline $95 \% \mathrm{Cl}$ & $2.56-2.79$ & $2.85-3.87$ & $4.76-6.55$ & $2.27-3.56$ & $2.08-3.55$ & $2.95-4.95$ & $6.96-11.89$ & $0.02-2.23$ & $0.20-2.97$ & $4.99-12.78$ & $3.66-13.19$ & $0.00-0.00$ & $2.78-3.00$ \\
\hline Q20-Q26 cases & 7033 & 2926 & 1768 & 400 & 1209 & 253 & 227 & 41 & 189 & 74 & 59 & 4 & 14,183 \\
\hline ¥CHD prev., & 9.29 & 58.86 & 64.51 & 14.76 & 59.71 & 16.64 & 38.21 & 11.55 & 59.76 & 32.87 & 41.42 & 6.24 & 15.53 \\
\hline $95 \% \mathrm{Cl}$ & $9.08-9.51$ & $56.73-60.99$ & $61.50-67.51$ & $13.31-16.21$ & $56.34-63.08$ & $14.59-18.69$ & $33.24-43.18$ & $8.01-15.08$ & $51.24-68.27$ & $25.38-40.36$ & $30.85-51.98$ & $0.12-12.36$ & $15.27-15.79$ \\
\hline Q36 cases & 1466 & 100 & 56 & 78 & 38 & 33 & 26 & 19 & 6 & 9 & 11 & 2 & 1,844 \\
\hline Cleft lip prev., & 1.94 & 2.01 & 2.04 & 2.88 & 1.88 & 2.17 & 4.38 & 5.35 & 1.90 & 4.00 & 7.72 & 3.12 & 2.02 \\
\hline $95 \% \mathrm{Cl}$ & $1.84-2.04$ & $1.62-2.41$ & $1.51-2.58$ & $2.24-3.52$ & $1.28-2.47$ & $1.43-2.91$ & $2.69-6.06$ & $2.94-7.76$ & $0.77-4.13$ & $1.39-6.61$ & $3.16-12.28$ & $-1.20-7.45$ & $1.93-2.11$ \\
\hline Q37 cases & 1595 & 160 & 266 & 150 & 122 & 92 & 84 & 12 & 16 & 19 & 8 & 5 & 2,529 \\
\hline $\begin{array}{l}\text { Cleft lip/palate } \\
\text { prev., }\end{array}$ & 2.11 & 3.22 & 9.71 & 5.53 & 6.03 & 6.05 & 14.14 & 3.38 & 5.06 & 8.44 & 5.62 & 7.80 & 2.77 \\
\hline $95 \% \mathrm{Cl}$ & $2.00-2.21$ & $2.72-3.72$ & $8.54-10.87$ & $4.65-6.42$ & 4.96-7.09 & 4.82-7.29 & 11.11-17.16 & $1.47-5.29$ & $2.89-8.21$ & $4.65-12.24$ & $1.72-9.51$ & $0.96-14.64$ & $2.66-2.88$ \\
\hline Q66 cases & 1171 & 192 & 190 & 197 & 158 & 164 & 115 & 44 & 99 & 5 & 4 & 2 & 2,341 \\
\hline Talipes prev., & 1.55 & 3.86 & 6.93 & 7.27 & 7.80 & 10.79 & 19.36 & 12.39 & 31.30 & 2.22 & 2.81 & 3.12 & 2.56 \\
\hline $95 \% \mathrm{Cl}$ & $1.46-1.64$ & $3.32-4.41$ & 5.95-7.92 & $6.25-8.28$ & 6.59-9.02 & $9.14-12.44$ & $15.82-22.89$ & $8.73-16.05$ & 25.13-37.47 & $0.27-4.17$ & $0.06-5.56$ & $-1.20-7.45$ & $2.46-2.67$ \\
\hline Q89.4 cases & 128 & 12 & 0 & 7 & 1 & 0 & 0 & 0 & 0 & 0 & 1 & 0 & 149 \\
\hline $\begin{array}{l}\text { Conjoined-twins } \\
\text { prev., }\end{array}$ & 0.17 & 0.24 & 0.00 & 0.26 & 0.05 & 0.00 & 0.00 & 0.00 & 0.00 & 0.00 & 0.70 & 0.00 & 0.16 \\
\hline $95 \% \mathrm{Cl}$ & $0.14-0.20$ & $0.10-0.38$ & $0.00-0.00$ & $0.07-0.45$ & $-0.05-0.15$ & $0.00-0.00$ & $0.00-0.00$ & $0.00-0.00$ & $0.00-0.00$ & $0.00-0.00$ & $-0.67-2.08$ & $0.00-0.00$ & $0.14-0.19$ \\
\hline Q90 cases & 2929 & 491 & 444 & 355 & 224 & 176 & 97 & 34 & 55 & 27 & 21 & 15 & 4,868 \\
\hline $\begin{array}{l}\text { Down syndrome } \\
\text { prev., }\end{array}$ & 3.87 & 9.88 & 16.20 & 13.10 & 11.06 & 11.58 & 16.33 & 9.58 & 17.39 & 11.99 & 14.74 & 23.40 & 5.33 \\
\hline $95 \% \mathrm{Cl}$ & $3.73-4.01$ & $9.00-10.75$ & $14.69-17.71$ & $11.74-14.46$ & $9.61-12.51$ & $9.87-13.29$ & $13.08-19.57$ & $6.36-12.79$ & $12.79-21.98$ & $7.47-16.52$ & $8.44-21.05$ & $\begin{array}{l}11.56- \\
35.25\end{array}$ & $5.18-5.48$ \\
\hline $\begin{array}{l}\text { Number of } \\
\text { semesters/total }\end{array}$ & $6 / 6$ & $6 / 6$ & $2 / 6$ & $4 / 6$ & $6 / 6$ & $6 / 6$ & $2 / 6$ & $6 / 6$ & $6 / 6$ & $5 / 6$ & $4 / 6$ & $1 / 6$ & $60 / 72$ \\
\hline Number of births & $7,566,872$ & 497,100 & 274,080 & 271,025 & 202,481 & 152,023 & 59,416 & 35,507 & 31,629 & 22,511 & 14,246 & 6,409 & $9,133,299$ \\
\hline
\end{tabular}

+ prev., $95 \% \mathrm{Cl}=$ prevalence, $95 \%$ Confidence Intervals

$\mp C H D=$ Congenital heart diseases 
Supplementary material

Table S2. International Classification of Diseases - 10 codes used in the ReLAMC form Selected Anomalies

\begin{tabular}{|l|l|l|}
\hline Códigos CIE-10 & Description & Example or Observation \\
\hline A50 + Q86.8 & Congenital syphilis & $\begin{array}{l}\text { Embryopathy with or without natal } \\
\text { infection }\end{array}$ \\
\hline B24+ Q86.8 & $\begin{array}{l}\text { Unspecified human immunodeficiency } \\
\text { virus disease [HIV] }\end{array}$ & $\begin{array}{l}\text { Embryopathy with or without natal } \\
\text { infection }\end{array}$ \\
\hline E00 & Congenital iodine deficiency syndrome & \\
\hline E25 & $\begin{array}{l}\text { Congenital adrenogenital disorders with } \\
\text { enzyme deficiency }\end{array}$ & Congenital adrenal hyperplasia \\
\hline E70 & $\begin{array}{l}\text { Phenylketonuria and other disorders of } \\
\text { aromatic aa metabolism }\end{array}$ & \\
\hline $\mathbf{H 9 0 0}$ & Triple pregnancy & Congenital deafness \\
\hline $\mathbf{0 3 0 . 0}$ & Conductive and sensorineural hearing loss & \\
\hline & Inguinal hernia & \\
\hline
\end{tabular}




\begin{tabular}{|c|c|c|}
\hline 030.2 & Quadruple pregnancy & \\
\hline 036.2 & Maternal care for hydrops fetalis & $\begin{array}{l}\text { Hydrops fetalis not associated with } \\
\text { isoimmunization }\end{array}$ \\
\hline 036.5 & Maternal care for fetal growth deficit & PEG \\
\hline 040 & Polyhydramnios & \\
\hline 041.0 & Oligohydramnios & \\
\hline P35.0 + Q86.8 & $\begin{array}{l}\text { Congenital infection due to congenital } \\
\text { rubella }\end{array}$ & $\begin{array}{l}\text { Embryopathy with or without natal } \\
\text { infection }\end{array}$ \\
\hline P35.1 + Q86.8 & $\begin{array}{l}\text { Congenital infection due to cytomegalic } \\
\text { virus }\end{array}$ & $\begin{array}{l}\text { Embryopathy with or without natal } \\
\text { infection }\end{array}$ \\
\hline P35.2 + Q86.8 & Congenital infection due to herpes simplex & $\begin{array}{l}\text { Embryopathy with or without natal } \\
\text { infection }\end{array}$ \\
\hline$P 35.8+Q 86.8$ & $\begin{array}{l}\text { Congenital infection due to chickenpox } \\
\text { and other congenital viral diseases }\end{array}$ & $\begin{array}{l}\text { Embryopathy with or without natal } \\
\text { infection }\end{array}$ \\
\hline P37.1 + Q86.8 & $\begin{array}{l}\text { Congenital infection due to Toxoplama } \\
\text { gondii }\end{array}$ & $\begin{array}{l}\text { Embryopathy with or without natal } \\
\text { infection }\end{array}$ \\
\hline P94.1 & Congenital hypertonia & \\
\hline P94.2 & Congenital hypotonia & \\
\hline
\end{tabular}




\begin{tabular}{|l|l|l|} 
Q00 & Anencephaly & $\begin{array}{l}\text { Includes craniorachischisis and } \\
\text { iniencephaly }\end{array}$ \\
\hline Q01 & Encephalocele & \\
\hline Q02 & Microcephaly & \\
\hline Q03 & Hydrocephalus & \\
\hline Q05 & Arrhinencephaly and Holoprosencephaly & Includes Ciclopia (Q87.0) \\
\hline Q11.1;Q.11.2 & Spina bifida & \\
\hline Q12.0 & Anophthalmia / Microphthalmia & \\
\hline Q15.0 & Congenital cataract & \\
\hline Q16.0; Q17.2 & Congenital glaucoma & \\
\hline Q20.0 & Anotia / Microtia & \\
\hline Q20.1 & Common trunk arteriosus & \\
\hline Q20.3 & $\begin{array}{l}\text { Transposition of the great vessels in the } \\
\text { right ventricle }\end{array}$ & \\
\hline Q20.4 & Ventriculoarterial connection mismatch & \\
\hline & Dentricular septum defect & \\
\hline
\end{tabular}




\begin{tabular}{|l|l|l|}
\hline Q21.1 & Atrial septum defect & \\
\hline Q21.2 & Atrioventricular septal defect & \\
\hline Q21.3 & Tetralogy of Fallot & \\
\hline Q22.0 & Pulmonary valve atresia & \\
\hline Q22.4 & Congenital pulmonary valve stenosis & \\
\hline Q22.5 & $\begin{array}{l}\text { Congenital stenosis / atresia of the } \\
\text { tricuspid valve }\end{array}$ & \\
\hline Q23.0 & Ebstein anomaly & \\
\hline Q23.4 & Congenital aortic valve stenosis / atresia & \\
\hline Q25.1 & Left heart hypoplasia syndrome & \\
\hline Q25.2 & & Excludes cleft lip \\
\hline Q26.2 & Cotal anomalous connection of the & \\
\hline Q36 cleft palate & Choanal atresia & \\
\hline & Atresia of the aorta & \\
\hline & Tip cleft & \\
\hline
\end{tabular}




\begin{tabular}{|l|l|l|}
\hline Q37 & Cleft palate with cleft lip & \\
\hline Q39.0 ... Q39.4 & $\begin{array}{l}\text { Esophageal atresia / stricture with or } \\
\text { without fistula }\end{array}$ & \\
\hline Q41.0 & $\begin{array}{l}\text { Absence, atresia, and congenital stenosis } \\
\text { of the duodenum }\end{array}$ & \\
\hline Q41.1.... Q41.9 & Other small bowel atresia / stenosis & $\begin{array}{l}\text { Other absences, atresias, and stenosis } \\
\text { of the small intestine }\end{array}$ \\
\hline Q42 & $\begin{array}{l}\text { Anorectal and large bowel atresia / } \\
\text { stenosis }\end{array}$ & \\
\hline Q43.1 & Hirschsprung's disease & \\
\hline Q44.2; Q44.3 & Atresia and stenosis of the bile ducts & \\
\hline Q53 & Cryptorchidism & \\
\hline Q54, excl. Q54.4 & Hypospadias & \\
\hline Q56 & Indeterminate sex & \\
\hline Q60.0; Q60.1; Q60.2 & Renal agenesis & \\
\hline C61 & & \\
\hline
\end{tabular}




\begin{tabular}{|l|l|l|}
\hline Q64.0 & Epispadias & \\
\hline Q64.1 & Urinary bladder exstrophy & \\
\hline $\begin{array}{l}\text { Q66.0 } \\
\text { only accessory hallux }\end{array}$ & Talipes equinovarus & \\
\hline $\begin{array}{l}\text { Some Q69.0; some Q69.2 } \\
\text { excluding accessory hallux }\end{array}$ & Polydactyly, post-axial & \\
\hline Q69.9; some Q69.0 & Polydactyly, other or unspecified & \\
\hline Q70 & & \\
\hline Q71; Q72; Q73 & Syndactyly & \\
\hline $\begin{array}{l}\text { Q71.0; Q71.2; Q71.3; } \\
\text { Q72.0; Q72.2; Q72.3; } \\
\text { Q73.0 }\end{array}$ & Transverse reduction & \\
& & \\
\hline Q71.1; Q72.1; Q72.4; & Intercalary reduction & \\
\hline Q73.1 & & \\
\hline
\end{tabular}




\begin{tabular}{|l|l|l|}
$\begin{array}{l}\text { Q71.6; Q71.8; Q71.9; } \\
\text { Q72.7; Q72.8; Q72.9; }\end{array}$ & Other reduction or not specified & \\
Q73.8 & Arthrogryposis multiplex congenita & \\
\hline Q74.3 & Craniosynostosis & \\
\hline Q75.0; Q75.1 & $\begin{array}{l}\text { Congenital malformations of the spine and } \\
\text { bone thorax }\end{array}$ & \\
\hline Q76 & Osteochondrodysplasias & \\
\hline Q77; Q78.1...Q78.5 & Imperfect osteogenesis & \\
\hline Q78.0 & $\begin{array}{l}\text { Diaphragmatic hernia and other } \\
\text { abnormalities }\end{array}$ & \\
\hline Q79.0; Q79.1 & Omphalocele & \\
\hline Q79.2 & Gastroschisis & \\
\hline Q79.3 & Prune belly or prune abdomen & \\
\hline Q79.4 & Eptcohol & \\
\hline Q80 & Congenital ichthyosis & \\
\hline Q81 & & \\
\hline Q86.0 & & \\
\hline
\end{tabular}




\begin{tabular}{|l|l|l|} 
& $\begin{array}{l}\text { Q.87 } \\
\text { (not elsewhere classified) }\end{array}$ & \\
\hline Q89.4 & Conjoined twins & \\
\hline Q90 & Down's Syndrome & \\
\hline Q91.0 ...Q91.3 & Trisomy 18 & \\
\hline Q91.4.... Q91.7 & Trisomy 13 & \\
\hline Q92; Q93 & $\begin{array}{l}\text { Other abnormalities of autosomes, not } \\
\text { elsewhere classified }\end{array}$ & \\
\hline Q96 & Turner syndrome & \\
\hline Q97; Q98; Q99 & $\begin{array}{l}\text { Other abnormalities of the sex } \\
\text { chromosomes, not elsewhere classified }\end{array}$ & \\
\hline Q89 & Other congenital anomalies & Excludes Q89.4 \\
\hline
\end{tabular}

